tion." The history and diagnosis was given, and in closing I said: "The stomach symptoms disappeared, but what I wish to show in this case is the complete disappearance of the constipation, the patient's boweis moving regularly once and twice per diem." I still have the original paper from which these quotations are taken. Very truly yours,

E. R. Gardner, M.D.

\section{Mark Twain and "The Doctor" in Innocents Abroad.} Chicago, April 23, 1901.

To the Editor:-Every little while there appears a statement in one of our medical journals concerning some doctor who is or was-for this statement usually appears in an obituary notice "the original of Mark Twain's doctor in 'Innocents Abroad." "There is, accordingly, a possibility that the orig. inal doctor of "Innocents Abroad" may become as numerous as the original Uncle Tom of Mrs. Stowe's famous novel. I have no doubt that these statements are all made in good faith; the explanation doubtless being that the particular person of whom the statement is made has been such a jovial, clever good fellow that he might have been the original of Mark Twain's doctor even if he is not. and so the tradition had gradually grown up around him.

In order to settle the question $\mathrm{I}$ wrote to $\mathrm{Mr}$. S. L. Clemens (Mark Twain) a fow days ago calling attention to the number of the originals of his doctor, and asking him to let me know who, if anybody, was the original. The following reply from him answers that question:

New Yonk, April 15, 1901.

Dear sir:-It is true, as you say, that doctor is multiplying from year to year. I have six of him on my list already. I do not remember the one which you cnclose. The real one was Dr. A. Reeves Jackson, of Chicago, whose too early death I still lament. Very truly yours.

Wm. Allen Pusey, Esq., Chicago, Ill.

It must be a source of some satisfaction to those who knew D:. Jackson, with all his charming and original qualities, to know that these have been immortalized in Mark Twain's famous character. Yours truly, Wy. Allen Pusey, M.D.

\section{Brewer's Yeast in Tuberculosis.}

Buffalo, N. Y., April, 27, 1901.

T'o the Editor:--I was interested in the editorial on "Gen eral Secondary Infection in the Course of Chronic Pulmonary Tuberculosis." It is important to know that these secondary pyogenie infections occur in tuberculous cases, and they, more than the primary bacillary infection, have to do with many of the annoying symptoms, namely: chills, morning and evening rise of temperature, hectic flush, increasing pallor, night sweats, etc. Many remedies have been recommended to combat these symptoms, especially the night sweats, with but little effect. Some time ago, being interested in the subject of tonsillar infection, I saw, through the courtesy of Dr. Charles Carey, of Buffalo, a case in which, through a pyogenic infection of the tonsil, there followed a retropharyngeal abscess and a pyemia with many metastatic abscesses. Dr. Roswell Park opened the retropharyngeal abscess, but the metastatic ones appeared from time to time in various parts of the skin-surface.

Large quantities of brewer's yeast were given the patient 2 to 4 ounces every three or four hours. It was well tolerated and the patient has made a good recovery. Since this time I have used the brewer's yeast to combat the secondary pyogenic symptoms of ulcerating tubercular cases, and in the two cases in which there were chills, hectic flushes. morning decline, evening rise of temperature has remained normal. There are no further chills, no hectic flushes and no night sweats.

The remedy is easily obtained fresh from any brewery. It may be taken in a tumbler without the addition of other liquid, and my experience is that it is well borne. If the stomach can not tolerate it a rectal enema of double the quantity may be given.

It has been shown by Vaughan and others that the nucleins of the body have much to do with giving to an organism its immunity. The various organs generating neutro-albu- min and nucleinic acid give to the body a substance which is destructive to micro-organisms and their toxins. Brewer's yeast contains nucleinic acid and therefore is an excellent therapeutic measure, and one which to my knowledge $I$ have not seen recommended as such for pyogenic infection, whether a pyemia, septicopyemia, or the secondary infections in tuberculosis, diabetes, typhoid, carcinoma, etc. I have noticed yeast nuclein recommended to be given hypodermically in septicemia, but have not seen brewer's yeast mentioned.

Julius Ullman, M.D.

\section{Association Zlews.}

\section{Annual A.nnouncement.}

The fifty-second annual session (54th year) of the AmErican Medical Association will be held in St. Paul, Minn., on Tuesday, Wednesday, Thursday and Friday, June 4, 5, 6 and 7 , commencing on Tuesday at 11 a. m.

\section{DELEGATES.}

The delegates shall receive their appointment from permanently organized state medical societies, and such county and district medical societies as are recognized by representation in their respective state societies, from the medical department of the Army, the Navy and the Marine-Hospital Service of the United States, and from oral and dental societies in good standing. Provided, however, that no state, county or other auxiliary body sending representatives shall receive into its membership any one who may, after 1901, have received the degree of Doctor of Medicine on less than four years of graded instruction or an equivalent requirement.

Each delegate shall hold his appointment for one year, and until another is appointed to succeed him, and shall participate in all the business and the affairs of the Association.

Each state, county and district medical society, entitled to representation, shall have the privilege of sending to the AsSOCIATION one delegate for every ten of its regular resident members, and one for every additional fraction of more than half that number. Provided, however, that the number of delegates from any affiliated society shall not exceed the ratio of one in ten of the members of such society. The Army and Navy, and the Marine-Hospital Service of the United States shall be entitled to the same proportionate representation as that of affiliated medical societies.

No individual who shall be under sentence of expulsion or suspension from any state or local medical society of which he may have been a member, or whose name shall have been, for non-payment of dues, dropped from the rolls of the same, shall be received as a delegate to this Association, or be allowed any of the privileges of a member, until he shall have been relieved from the said sentence or disability by such state or local society, or shall have paid up all arrears of membership; nor shall any person not a member and supporter of a local medical society, where such a one exists, be eligible to membership in the american Medical association.

No one expelled from this Association shall be received at any time thereafter as a delegate or member, unless by a three-fourths vote of the members present at the meeting to which he is sent, or at which he is proposed.

\section{PERMANENT MEMBERS.}

The permanent members shall consist of all those who have served in the capacity of delegates, and of such other members as may receive the appointment by unanimous vote, and shall continue such so long as they remain in good standing in the body from which they were sent as delegates, and comply with the requirements of the By-Laws of the Association. Permanent members shall at all times be entitled to attend the meetings, and participate in the affairs of the Association, so long as they shall continue to conform to its regulations, but without the right of voting.

MEMBERS BY APPLICATION.

Members by application shall consist of such members of the state, county, and district medical societies entitled to repre- 